\title{
Pola Asuh Orangtua Bekerja Sebagai Pembentuk Perilaku Hidup Sehat Anak
}

\author{
Roudlotul Islamiyah \\ Universitas Negeri Yogyakarta \\ Email: roudlotulislamiyah84@gmail.com \\ Ambarsari Utamining Gustinah \\ Universitas Negeri Yogyakarta \\ Email: ambarsariuge14@gmail.com

\section{Sinta Maulida Hapsari} \\ Universitas Negeri Yogyakarta \\ Email: sintamaulida.haps@gmail.com
}

Article received: 27 Mei 2020, Review process: 06 Februari 2021,

Article Accepted: 11 Maret 2021, Article published: 30 Maret 2021

\begin{abstract}
This research is a research that discusses parenting parents who work in healthy lifestyles of young children. The objective to be achieved in this study is to determine the impact of parenting parents working as forming the healthy behavior of early childhood. The subjects of this study consisted of three families consisting of working couples and children attending one of the PAUD schools in Kediri with different forms of parenting. The method used in this research is descriptive qualitative research with data collected through observations, questionnaires, documentation, and interviews with the analysis of data reduction, displaying data, and concluded. The results obtained in this study are children in democratic parenting from working parents, all parts of a healthy life with a renewed spiritual, physical, and moral health. Children in authoritarian parenting from working parents, still need to discuss and be guided in courtesy, be encouraged in motor / physical activities, also be trained in toilet training while children in permissive parenting from working parents, must still be guided in all fields, both spiritual, physical and moral.
\end{abstract}

Keywords: parenting, working age, healthy life, early childhood

\begin{abstract}
Abstrak
Penelitian ini merupakan penelitan yang membahas tentang pola asuh orangtua yang bekerja dalam pola hidup sehat anak usia dini. Tujuan yang ingin dicapai dalam penelitian ini yaitu untuk mengetahui dampak pola asuh orangtua berkerja sebagai pembentuk prilaku hidup sehat anak usia dini. Subjek penelitian ini terdiri dari tiga keluarga yang terdiri dari pasangan yang bekerja dan anak yang bersekolah di salah satu sekolah PAUD di Kediri dengan bentuk pola asuh yang berbeda. Metode yang digunakan dalam penelitian ini yaitu penelitian kualitatif deskriptif dengan data yang dikumpulkan melalui pengamatan, angket,
\end{abstract}


dokumentasi, dan wawancara dengan analisis dengan reduksi data, menampilkan data, dan disimpulkan. Hasil yang didapatkan dalam penelitian ini yaitu anak-anak dalam pola asuh demokrasi dari orangtua yang bekerja, seluruh bagian dalam hidup sehat dengan spiritual, fisik, dan moral yang diperbarui dengan baik. Anak dalam pola asuh otoriter dari orangtua yang bekerja, masih harus membicarakankan dan dibimbing dalam hal santun santun, diberi semangat dalam kegiatan motorik / fisik, juga dilatih toilet training sedangkan anak dalam pola asuh permisif dari orangtua yang bekerja, masih harus dibimbing dalam segala bidang, baik spiritual, fisik, maupun moral.

Kata Kunci: pola asuh, usia bekerja, hidup sehat, anak usia dini

\section{PENDAHULUAN}

Pada masa modern ini, wanita memiliki ruang yang luas untuk mengeksplor dirinya dan melakukan semua hal tanpa harus khawatir untuk adanya diskriminasi tentang gender. Wanita tidak hanya berkewajiban untuk mengurus urusan rumah tangga saja tetapi dapat bekerja sesuai bidangnya. Ibu memiliki peranan paling utama dalam pengasuhan kepada anak sehingga ibu harus mampu memaikan perannya karena sangat dibutuhkan anak agar anak dapat tumbuh dengan baik (Wang, Huang, \& Kong, 2020). Tujuan seorang ibu bekerja atau masuk ruang publik yaitu membantu ayah atau kepala keluarga dalam mencukupi kebutuhan hidup seluruh keluarga tetapi bukan untuk melepaskan dari tanggung jawabnya sebagai ibu yaitu mengasuh anak-anak (Widiasari \& Pujiati, 2017:69). Seorang ibu pekerja di luar rumah atau perkantoran relatif tidak memiliki waktu yang banyak dengan anak memiliki dampak bagi keluarga baik negatif atau positif. Dampak negatif dan positif dari ibu yang bekerja menjadi sangat relatif dan di awal tahun pertama ketika ibu melakukan pekerjaan atau bekerja, dapat memberikan pengaruh negatif di kehidupan anak pada masa perkembangan selanjutnya (Rhamadani Santoso, Nasution, \& Sri Redjeki, 2016).

Data statistik yang diperoleh dari Badan Pusat Statistik (BPS) pada 2011 menunjukkan bahwa 93,44\% keluarga yaitu orangtua yang bekerja atau sibuk dan $100 \%$ wanita yang berada di Indonesia sebanyak $82,68 \%$ merupakan wanita bekerja (Shabarina, Mediani, \& Mardiah, 2018). Ibu bukannya satu-satunya yang berperan dalam keluarga, ayah juga sebagai kepala rumah tangga memiliki peran yang sama dalam mendidik anak. Ketidakhadiran atau kurangnya waktu anak bersama ayah yang terlalu sibuk bekerja juga akan memberikan dampak kepada perilaku dan hasil belajar anak di sekolah, misalnya agresi, kognitif, dan kenakalan pada anak sedangkan anak yang memiliki kedekatan dengan ayahnya atau ayah cukup mempunyai waktu dengan anaknya menjadikan anak akan lebih mudah mengatur emosinya (Cabrera, Volling, \& Barr, 2018).

Hasil penelitian dari Harmaini (2013) yang menyatakan bahwa orangtua yang berkerja menganggap bahwa fungsi keluarga yang terpenting yaitu pemenuhan kebutuhan secara ekonomi sedangkan fungsi yang lain baik psikis, emosinal, perhatian, kedekatan dan lainnya bukan menjadi kebutuhan pokok. Hal tersebut menjadi salah satu fokus yang harus diperhatikan oleh orangtua bahwa orangtua tidak hanya memiliki tanggung jawab dalam pemenuhan kebutuhan ekonomi saja tertapi berbagai fungsi yang lainnya. Keberhasilan dan kegagalan anak dalam berperilaku terutama perilaku hidup sehat sangat bergantung kepada 
pola asuh yang dimainkan oleh orangtua karena merupakan kunci kehidupan anak untuk masa depan atau masa perkembangannya (Garcia \& Serra, 2019). Hasil akhir atau masa dewasa anak dalam kehidupan akan sangat bergantung kepada pola asuh yang diberikan oleh orangtua kepada anak sehingga kedekatan orangtua terutama ibu dengan anak akan memberikan dampak terhadap kopetensi anak secara akademik dan sosial termasuk dengan perilaku hidup sehat anak (Gibbs, Forste, \& Lybbert, 2018). Kesibukan kedua orangtua dalam pekerjaannya membuat waktu bersama anak menjadi sangat terbatas sehingga kebersamaan dan kedekatan dalam memberikan segala pemahaman juga akan berdampak.

Orangtua bertanggung jawab untuk membentuk kepribadian dan karakter anak yang sesuai dengan kebiasaan baik yang dilakukan di kehidupan sehari-hari termasuk perilaku hidup sehat anak melalui pola asuh yang baik dan benar sehingga akan mampu bertanggung jawab atas dirinya sendiri di masa depannya (Muhadi, 2015). Kesibukan orangtua dalam bekerja bukan berarti dapat menghilangkan tanggung jawab untuk mengasuh, walaupun mayoritas waktu orangtua akan dihabiskan di tempat kerja dan orangtua hendaknya tetap mampu berinteraksi dengan anak dengan pengasuhan yang tepat ketika di rumah dan (Widiasari \& Pujiati, 2017). Berdasarkan pernyataan Kabid Rehabilitasisosial Dinas Sosial Kabupaten Kediri yaitu Dyah Saktiana mengatakan bahwa selama Januari hingga September 2019, terdapat 10 kasus penelantaran anak dan lansia oleh Dinas Sosial (Dinsos) Kabupaten Kediri dan penyebabnya adalah faktor ekonomi dan hubungan gelap dan kasus ini akan diproses secara hukum kepada orangtua dan keluarga yang melakukan penelantaran (Nugroho, 2019). Peran yang paling bertanggung jawab atas kesuksesan hidup anak dapat dilihat dari keluarga atau orangtua hingga penelantaran anak termasuk dengan tidak memperhatikan perilaku sehat anak di Indonesia yang telah diatur dalam undang-undang dan memiliki ancaman hukuman jika melakukannya.

Orangtua memiliki cara sendiri untuk mampu menjalankan tanggung jawabnya sebagai pusat pendidikan untuk anak. Pola asuh yang berbeda-beda dari ibu yang bekerja akan memberikan hasil yang berbeda pula kepada kehidupan anak termasuk pada perilaku hidup sehat anak. Pola asuh merupakan proses interaksi yang terjadi antara orangtua dan anak dengan melindungi, memelihara, mengarahkan tingkah laku, membantu dalam pembentukan kepribadaian, memberi makan, dan mampu hidup sehat dengan lingkungan (Haeriah, 2018). Pola asuh akan mempengaruhi karakter anak dan cara berfikir anak yang dilakukan secara turun termurun dan dipercaya pola asuh tersebut baik untuk anak (Siti Juwariah, 2019). Pola asuh orangtua pada dasarnya sama terdiri dari beberapa tipe atau model atau bentuk. Faktor pembedanya yaitu jika orangtua bekerja maka waktu dan interaksi orangtua dan anak terbatas. Keterbatasan itu yang menjadi permasalahan yang beranekaragam dari keluarga dengan pola asuh yang berbeda baik pola asuh yang dilakukan secara demokratis, otoriter, atau permisif.

Pada pola asuh demokratis yaitu pola asuh yang menekankan cinta kasih akan berdampak sangat baik bagi tumbuh kembang anak baik secara intelektual dan emosional anak (Berangka, 2018). Pola asuh demokratis terjadi karena sikap terbuka antara anak dan orangtuanya dengan membuat segala aturan atas persetujuan bersama dan anak sehingga anak bisa mengungkapkan perasaan, pendapat dan keinginannya dan orangtua hanya sebagai pemberi pertimbangan 
dan pendapat kepada anak atas segala kegiatan yang akan dipilih atau dilakukan anak (Muhadi, 2015).

Pada pola asuh permisif yaitu pola asuh yang diterapkan dengan memberikan kebebasan kepada anak tanpa pengawasan yang cukup untuk melakukan sesuatu (Haeriah, 2018). Pola asuh permisif yaitu pola asuh yang cenderung memberikan kebebasan atau serba boleh tanpa adanya kontrol sama sekali kepada anak sehingga memiliki indikasi memanjakan (Berangka, 2018). Pola asuh permisif yaitu pola asuh yang terlalu toleran dan mengabaikan segala kesalahan anak dan memberikan kebebasan penuh atas apa yang ingin dilakukannya kecuali dalam keterlibatan secara fisik (Farzana Bibi, 2013).

Pada pola asuh otoriter yaitu pola asuh yang diterapkan dengan batasanbatasan yang ketat dengan adanya hukuman dan paksaan serta pada memiliki keyakinan bahwa anak harus memiliki kepatuhan secara total kepada orangtua (Haeriah, 2018). Pola asuh otoriter yaitu pola asuh yang menekankan pada batasan dan larangan. Orang tua menghargai anak yang patuh terhadap yang diperintahkan dan tidak melawan karena orang tua berpandangan bahwa arahan dan pendapat mereka adalah yang paling baik dan benar (Berangka, 2018). Dampak pada pola asuh authoritative untuk anak yaitu anak dapat membangun rasa percaya, mengungkapkan pikiran, membuat keputusan sendiri, mandiri, bersikap tegas, dan percaya diri (Shabarina et al., 2018). Pola asuh otoriter merupakan pola asuh yang mengharuskan anak untuk selalu patuh dan menerima tuntutan yang diberikan oleh orangtua tanpa meminta pertimbangan anak dengan suatu perintah, cinta yang terbatas, dan kekuatan fisik (Farzana Bibi, 2013). Faktor yang mempengaruhi pola asuh antara lain agama, kepribadian, kultur, status ekonomi, usia, jenis kelamin, temprampen anak, latar belakang orangtua, dan media massa (Haeriah, 2018).

Ketiga pola asuh tersebut akan memberikan dampak yang berbeda-beda karena pengalaman yang dimiliki anak juga berbeda apalagi dalam pengembangan atau penanaman perilaku hidup sehat anak, baik secara spiritual, fisik, dan moral. Kelekatan atau kedekatan antara orangtua dan anak berdasarkan pola asuh dan lingkungan akan memberikan pemahaman anak tentang gaya hidup sehat atau perilaku hidup sehat anak (Hutchens \& Lee, 2018). Pola asuh merupakan perilaku yang dilakukan orangtua dalam memaksimalkan segala potensi dalam perkembangan dan pertumbungan terutama pada perilaku tumbuh kembang anak secara penuh baik berkaitan dengan spiritual, fisik, maupun moral anak (Padjrin, 2016).

Pola asuh yang berbeda juga dapat memberikan dampak-dampak yang berbeda pula kepada kehidupan anak, termasuk perilaku hidup sehat anak. Berdasarkan sata yang dikeluarkan oleh Riset Kesehatan Dasar (Riskesdas) yang berkaitan dengan perilaku hidup sehat anak di Indonesia terutama di Jawa Timur menunjukkan angka stanting di Jawa Timur cukup tinggi yaitu diatas $40 \%$ pada 2018 sehingga perilaku hidup sehat harus ditingkatkan seperti anjuran Gubernur Jawa Timur Khofifah Indar Parawansa (Marzuki \& Mahiruni, 2020). Pada masa virus Corona (Covid-19) yang melanda dunia saat ini, gerakan menumbuhkan perilaku hidup sehat juga sangat dibutuhkan oleh masyarakat Indonesia tertama untuk diajarkan kepada anak-anak. Pada Mei 2020, Jawa Timur merupakan provinsi kedua tertinggi dalam penyebaran virus Corona (Covid-19) di Indonesia. Hal tersebut menjadi sesuatu yang penting dalam memperkuat tekat dalam 
meningkatkan perilaku hidup sehat apalagi yang orangtuanya masih harus bekerja di luar rumah.

Perilaku Hidup Bersih dan Sehat (PHBS) merupakan segala perilaku kesadaran dalam menjaga kesehatan sehingga mampu berperan aktif dan mampu menolong dirinya sendiri dalam menjalankan kegiatan-kegitan kesehatan sebagai cerminan keluarga yang menjaga dan memperhatikan kesehatan seluruh anggota keluarga (Juliani, 2018). Perilaku sehat adalah suatu sikap terhadap sistem pelayanan kesehatan, menjaga makanan, minuman, dan lingkungan, mendapatkan zat gizi yang sesuai dengan kebutuhan, istirahat yang cukup, melakukan olah raga secara rutin, melakukan perawatan mulut dan gigi, supaya terhindar dari segala bentuk penyakit (Astuti, 2016).

Tujuan untuk hidup sehat dan memiliki tubuh ideal sangat berhubungan dengan kepercayaan diri dan segala bentuk pergeseran nilai-nilai yang ada dalam citra individu akan mempengaruhi tatanan dalam kehidupan sosial dan gaya hidup sehat yang terapkan dengan cara pandang masyarakat yang berbeda dari penampilan, kepribadian, dan bentuk tubuh yang proposional sehingga menarik perhatian (Susanti \& Kholisoh, 2018). Undang-Undang Kesehatan RI No.36 Tahun 2009 menyatakan bahwa "Kesehatan adalah keadaan sehat, baik secara fisik, mental, spritual maupun sosial yang memungkinkan setiap orang untuk hidup produktif secara sosial dan ekonomis" (Pemerintah Indonesia, 2009).

Berdasarkan teori yang diungkapkan para tokoh dapat disimpulkan bahwa perilaku hidup sehat yaitu upaya memperhatikan dan menjaga kesehatan baik secara fisik, mental, spritual maupun sosial dengan cara pandang baru masyarakat untuk menilai seorang individu. Penilaian tersebut bisa terlihat dari kepedulian seseorang terhadap penampilan dirinya, kepribadian seseorang maupun bentuk tubuh proposional (interaksi dengan orang lain) dan bentuk dari menjaga kesehatan anggota tubuh (fisik) adalah dengan menanamkan pendidikan toilet training pada anak. Segala perilaku hidup sehat tersebut bisa terbentuk jika anak diajarkan, dibiasakan, dan diberikan contoh oleh orangtua secara tepat tentang bagaimana cara berperilaku hidup sehat. Anak akan lebih mudah untuk menjalankan dalam penanaman perilaku hidup sehat jika dilakukan bersama orangtua dan keluarga lainnya sehingga pembiasaan tersebut bisa konsisten dengan pola asuh yang telah dilakukan baik oleh orangtua ataupun keluarga lainnya.

Berdasarkan latar belakang yang terlah dipaparkankan menjadi faktor penguat mengapa penelitian ini harus dilakukan. Penelitian ini akan mengupas dan mendeskripsikan tentang pola asuh orangtua yang bekerja yaitu demokratis, otoriter, dan permisif dalam membentuk perilaku hidup sehat baik secara spiritual, fisik, maupun moral anak usia dini.

\section{METODOLOGI}

Penilitian ini dianalisis dengan metode kualitiatif deskriptif dengan pengumpulan data melalui observasi, dokumentasi, angket, dan wawancara mendalam kepada guru sebagai pendidik yang memperhatikan perilaku anak di sekolah. Proses analisis melalui tiga tahapan analisis yaitu reduksi data, display data, dan kesimpulkan dan verifikasi data. Data angket didapatkan dari angket tentang pola asuh yang diisi oleh orangtua untuk menentukan subyek penelitian, data observasi didapatkan dari observasi perilaku hidup sehat anak dari aspek 
spiritual, fisik, dan moral anak yang terlihat di sekolah, data dokumentasi didapatkan dari combook atau buku penghubung antara orangtua dan guru, dan data wawancara mendalam didapatkan dari guru yang mengajar di kelas tersebut dengan menanyakan perilaku hidup sehat anak di sekolah. Data yang tidak sesuai dengan fokus penelitian akan dihilangkan atau dibuang dan data yang sesuai akan dianalisis dan dijabarkan menggunakan pendekatan deskriptif. Berikut ini panduan observasi dan wawancara dalam penelitian ini:

Tabel 1. Pedoman Observasi dan Wawancara

\begin{tabular}{cccc}
\hline No & Aspek & Sub Aspek & Sub-Sub Aspek \\
\hline 1 & Perilaku Hidup & Sehat Spiritual & Kebersihan \\
\cline { 3 - 3 } & & & Ibadah \\
\cline { 3 - 3 } & & & Akhlak \\
\cline { 3 - 3 } & & & Budi pekerti \\
\cline { 3 - 3 } & & Sehat Fisik & Kesehatan \\
\cline { 3 - 3 } & & Kerapian \\
\cline { 3 - 3 } & & Sehat Moral & Toilet training \\
\cline { 3 - 3 } & & & Berani \\
\cline { 3 - 3 } & & Semangat \\
& & Disiplin \\
& & Bahagia \\
& & \\
& &
\end{tabular}

Pemilihan subjek dipilih menggunakan teknik sampel nonprobability sampling yaitu purposive sample (pemilihan sampel dengan pertimbangan tertentu). Kriteria pemilihan sampel yaitu: 1) Keluarga yang memiliki anak yang memiliki usia 4-6 tahun bersekolah di salah satu sekolah TK (Taman Kanakkanak) di Kediri dengan $80 \%$ kedua orangtua siswanya merupakan pekerja atau memiliki pekerjaan di luar rumah.; 2) Pola asuh yang berbeda yaitu demokratis, otoriter, dan permisif antara 3 keluarga yang dianalisis berdasarkan Combook (Communitation Book).; dan 3) Memiliki hasil atau score tertinggi dalam angket tentang pola asuh yang diberikan dengan setiap pola asuh yang berbeda.

Tabel 2. Intrumen Angket Pola Asuh (Pengambilan Sampel)

\begin{tabular}{|c|c|c|c|}
\hline No & Aspek & Sub Aspek & Sub-Sub Aspek \\
\hline \multirow[t]{4}{*}{1} & Pola & Pola Asuh & Bercakap-cakap/diskusi antara orangtua dan anak. \\
\hline & Asuh & Demokrati & Kerja sama antara orang tua dan anak secara baik. \\
\hline & & $\mathrm{s}$ & Orangtua mengakui eksistensi anak. \\
\hline & & & $\begin{array}{l}\text { Kebebasan berekspresi dengan pengawasan orang } \\
\text { tua. }\end{array}$ \\
\hline \multirow[t]{4}{*}{2} & & \multirow{4}{*}{$\begin{array}{l}\text { Pola Asuh } \\
\text { Permisif }\end{array}$} & Bercakap-cakap/diskusi antara orangtua dan anak. \\
\hline & & & Kerja sama yang baik antara anak dan orangtua. \\
\hline & & & Orangtua mengakui eksistensi anak. \\
\hline & & & $\begin{array}{l}\text { Kebebasan berekspresi dengan pengawasan orang } \\
\text { tua. }\end{array}$ \\
\hline \multirow[t]{2}{*}{3} & & Pola asuh & Bercakap-cakap/diskusi antara orangtua dan anak. \\
\hline & & & Kerja sama yang baik antara anak dan orangtua. \\
\hline
\end{tabular}


Orangtua mengakui eksistensi anak.

Kebebasan berekspresi dengan pengawasan orang tua.

Penelitian ini menggunakan subjek tiga keluarga yang kedua orangtua (ibu dan ayah) bekerja dengan pola asuh yang berbeda yaitu demokratis, otoriter, dan permisif. Pemilihan keluarga yang memiliki tiga pola asuh yang berbeda berdasarkan score tertinggi dalam angket yang disebar kepada orangtua dan diperkuat dengan Combook (Communitation Book) atau buku penghubung antara orangtua dengan guru. Hal tersebut dapat dianalisis dari anggapan atau respon yang diberikan oleh orangtua atas laporan perilaku anak di sekolah dari guru. Guru juga menanyakan pertanyaan seperti apakah orangtua selalu mengulang pembelajaran di sekolah pada saat di rumah atau tidak dan pertanyaan lainnya. Keluarga dengan pola asuh demokratis biasanya tidak memaksa anak untuk melakukan pengulangan dalam pembelajaran tapi mencari celah agar anak mau melakukannya. Keluarga dari pola asuh otoriter biasanya memaksa anak untuk mengulang tanpa melihat perasan anak (capek atau tidak). Keluarga dengan pola asuh permisif biasanya membiarkan anak untuk mau atau tidaknya mengulang pembelajaran di sekolah.

Tabel 3. Hasil Angket Pola Asuh Orangtua (Pengambilan Sampel)

\begin{tabular}{|c|c|c|c|}
\hline No & Pola Asuh & Score & $\begin{array}{l}\text { Jumlah } \\
\text { Orangtua }\end{array}$ \\
\hline \multirow[t]{8}{*}{1} & Demokratis & 7 & 2 \\
\hline & & 8 & 2 \\
\hline & & 10 & 5 \\
\hline & & 12 & 11 \\
\hline & & 13 & 3 \\
\hline & & 14 & 3 \\
\hline & & 16 & 1 \\
\hline & \multicolumn{2}{|c|}{ Jumlah } & 27 \\
\hline \multirow[t]{8}{*}{2} & Permisif & 6 & 3 \\
\hline & & 7 & 4 \\
\hline & & 9 & 3 \\
\hline & & 11 & 7 \\
\hline & & 13 & 3 \\
\hline & & 15 & 3 \\
\hline & & 16 & 1 \\
\hline & \multicolumn{2}{|c|}{ Jumlah } & 27 \\
\hline \multirow[t]{9}{*}{3} & \multirow[t]{9}{*}{ Otoriter } & 6 & 6 \\
\hline & & 8 & 5 \\
\hline & & 9 & 3 \\
\hline & & 10 & 2 \\
\hline & & 11 & 7 \\
\hline & & 13 & 1 \\
\hline & & 14 & 2 \\
\hline & & 16 & 1 \\
\hline & & & 27 \\
\hline
\end{tabular}


Berdasarkan data tersebut maka dari 27 keluarga, terpilihlah tiga keluarga dengan score tertinggi yaitu 16 pada masing-masing pola asuh yang menandakan bahwa keluarga/orangtua tersebut lebih dominan pada pola asuh yang sesuai dengan nilai atau score tertingginya. Setiap item indikator menggunakan 4 katogori yaitu selalu (score 4), sering (score 3), kadang-kadang (score 2), dan tidak pernah (score 1) dalam pengisian angket untuk mewakili setiap pola asuh yaitu sebagai berikut: 1) Keluarga pertama yang kedua orangtuanya adalah Dokter; 2) Keluarga kedua yang berprofesi sebagai TNI (ayah) dan Perawat (ibu); 3) Keluarga ketiga yang berprofesi PNS (ayah) dan Agen Biro Perjalan (ibu). Hasil angket tersebut yang akhirnya menjadi dasar mengapa penelitian ini menggunakan 3 keluarga tersebut. Berdasarkan tiga sampel keluarga yang telah didapatkan maka penelitian ini akan mendeskripsikan perilaku hidup sehat anak yang nampak dari perilakunya di sekolah atau PAUD.

\section{HASIL DAN PEMBAHASAN}

Perilaku hidup sehat anak dapat terlihat pada saat anak berada di Sekolah dan berinterkasi dengan teman dan guru juga karyawan di Sekolah. Bentuk perilaku yang ditunjukan anak berbeda-beda. Beberapa hal bisa mendasari perbedaan bentuk perilaku hidup sehat anak. Perbedaan tersebut bisa terjadi karena pola asuh orangtua yang berbeda, apalagi ketika kedua orangtuanya bekerja. Berikut ini hasil penelitian dari perilaku hidup sehat anak dari orangtua yang bekerja, baik secara spiritual, fisik, dan moral yang diperoleh dari observasi kepada anak, dokumentasi (combook) kepada orangtua, dan wawancara mendalam kepada guru.

\section{Perilaku hidup sehat spiritual}

Bentuk perilaku hidup sehat spiritual dari anak dapat dilihat dari anak mampu dan mau untuk menjaga kebersihan diri dan lingkungannya, ibadah, akhlak, dan budi pekerti anak atau hubungan dengan orang lain. Anak dalam pola asuh orangtua yang demokratis, sangat terlihat dari anak selalu membuang sampah ditempatnya tanpa diperintah dan anak juga tak segan untuk membuang sampah yang bukan miliknya ke tempat sampah. Anak dalam pola asuh orangtua yang otoriter, masih belum menunjukkan sikap menjaga kebersihan, misalnya ketika makan belepotan dan tercecer dimana-mana. Anak dalam pola asuh orangtua yang permisif, ke sekolah dengan berseragam rapi dan atribut lengkap tetapi kuku sering kotor dan tidak dipotong.

Kegiatan beribah menjadi kunci bagaiman kesehatan spiritual anak dibentuk dengan baik. Sekolah ini membiasakan anak untuk melakukan sholat dhuha. Anak dalam pola asuh orangtua yang demokratis, menunjukkan bahwa anak mengikuti kegiatan sholat dhuha dengan tertib, hanya saja terkadang suka mengintip (membuka mata) ketika berdoa. Anak dalam pola asuh orangtua yang otoriter, menunjukkan perilaku tertib dalam beribadah (mengikuti sholat dhuha dan susyu' dalam berdoa). Anak dalam pola asuh orangtua yang permisif, menunjukkan perilaku kurang tertib ketika sholat dhuha. Masih melamun dan mengajak temannya ngobrol.

Akhlak yang baik juga merupakan kesehatan spiritual. Anak dalam pola asuh orangtua yang demokratis, menunjukkan sikap yang baik, seperti ketika mau makan, anak bedoa terlebih dahulu dan makan dengan tangan kanan. Anak dalam pola asuh orangtua yang otoriter, bisa berperilaku sesuai aturan dan 
kebiasaan yang diajarkan. Anak dalam pola asuh orangtua yang permisif, masih berperilaku sesukanya sendiri.

Tidak hanya dengan menjaga kebersihan diri dan lingkungan, kegiatan beribadah, dan akhlak yang baik. Hubungan atau interaksi anak dengan teman dan guru juga dapat dilihat sebagai bentuk kesehatan spriritul. Anak dalam pola asuh orangtua yang demokratis, bisa menunjukan perilaku yang sopan seperti menunduk ketika lewat di depan guru dan mengucapkan permisi. Anak dalam pola asuh orangtua yang otoriter, masih sering diingatkan ketika melakukan sesuatu, misalnya ketika berjalan di depan guru harus mengucapkan permisi. Anak dalam pola asuh orangtua yang permisif, masih harus diingatkan agar santun dan ramah kepada orang lain. Kesadaran orangtua dalam memberikan pembiasaan hidup sehat spiritual juga menjadi tanggung jawab yang tidak mudah untuk dilakukan orangtua. Guru menjelaskan dalam wawancara yaitu: "Sebenarnya tentang spiritual anak, ya soal kebiasaan sholat dan cara berdoa tidak bisa dibiasakan di sekolah saja. Orangtua sebaiknya membiasakan juga, ya misalnya waktu berdoa, gimana anak dibiasakan tangan anak dalam posisi berdoa, tidak melamun, atau masih melihat kanan kiri. Gitu lah mbak."

\section{Perilaku hidup sehat fisik}

Sehat secara fisik akan selalu menunjuk kesehatan yang tampak secara fisik sebagai faktor utama dalam penentuannya. Upaya yang diperlihatkan anak dalam mengikuti segala kegiatan fisik motorik di sekolah menjadi usaha yang baik untuk kesehatan fisik anak. Beberapa perilaku yang menunjukkan kesehatan fisik adalah kegiatan untuk menjaga kesehatan, kerapian dan toilet training.

Kegiatan fisik motorik anak di sekolah menjadi kunci bagaimana anak mampu mamaksimalkan pertumbuhan dan perkembangannya secara fisik dengan baik. Anak dengan pola asuh yang demokratis, aktif mengikuti kegiatan di sekolah seperti menari dan yoga, hanya beberapa kali izin tidak masuk karena sakit dan gizi makanan anak terpenuhi dengan baik. Anak dengan pola asuh yang otoriter, aktivitasnya di rumah dibatasi sehingga anak jadi terlihat kurang menguasai kegiatan yang melibatkan motoriknya dan gizi makanan anak terpenuhi dengan baik. Anak dengan pola asuh yang permisif, anak yang sehat dan bisa mengikuti seluruh kegiatan motorik dengan baik juga pertumbuhannya berkembang dengan stabil dan gizi makanan anak terpenuhi dengan baik.

Kerapian menjadi salah satu bentuk dari kesehatan fisik anak. Anak dalam pola asuh orangtua yang demokratis, memakai seragam sekolah dengan rapi dan lengkap dan setiap hari berganti kaos kaki dengan selalu wangi dan bersih. Anak dalam pola asuh orangtua yang otoriter, anak selalu rapi dan memakai atribut lengkap di sekolah. Anak dalam pola asuh orangtua yang permisif, anak selalu datang ke sekolah dengan rapi bahkan gaya berpakaian menirukan gaya berpakaian gurunya, seperti memakai handsocks/ikat kepala.

Kesehatan fisik juga mengutamakan bagaimana anak mampu melakukan toilet training dengan tepat. Toilet training dianggap sebagai bagaian dari kesehatan fisik yang membantu dalam mencegah segala bentuk penyakit. Anak dengan pola asuh demokratis, anak sudah bisa melakukan toilet trainging dengan mandiri, mulai dari cara izin yang benar. Anak bisa melepas celana dengan mandiri, dan membersihkan diri (menyiram dan cusi tangan), hanya saja untuk melepas / memakai legging masih perlu bantuan. Anak dengan pola asuh otoriter, Anak masih kesulitan dalam melakukan toilet training karena di rumah masih 
sering dibantu oleh orang dewasa. Anak dengan pola asuh permisif, Anak sudah bisa melakukan toilet training dengan mandiri namun terkadang lupa ketika memakai celana/legging tidak di kamar mandi justru memakainya di luar kamar mandi.

Perilaku hidup sehat fisik anak juga sangat bergantung pada pola asuh orangtua. Setiap orangtua berkewajiban untuk itu. Kesadaran orangtua dapat dilihat dari jawaban atau tanggapan orangtua atas laporan di combook yang ditulis oleh guru. Salah satu contoh yaitu ketika guru melaporkan bahwa anak tidak mau memakan sayur (brokoli dll), orangtua yang demokratis, menjawab pada buku penghubung bahwa orangtua sudah menanyakan anak mengapa tidak mau makan sayur dan mencoba terus dengan mencampurkan sayur pada telur. Orangtua yang otoriter, menjawab pada buku penghubung bahwa anak dipaksa sampai anak mau makan sayur. Orangtua yang permisif, menjawab pada buku penghubung bahwa sudah mencoba memberi makan sayur tetapi karna anak tidak mau, ya sudah dibiarkan. Hal tersebut sejalan dengan hasil wawancara yang dilakukan pada guru yaitu: "Saya sudah mencoba mengomunikasikan kepada orangtua anak tetapi kembali pada keluarga atau orangtua, mau membantu dalam melaksanakan atau tidak. Ya, seperti soal anak yang gak mau makan sayur."

\section{Perilaku hidup sehat moral}

Perilaku hidup sehat moral menjadi hal yang tak kalah pentingnya menyangkut perilaku hidup sehat. Anak dengan kesehatan mental yang baik, menjadikan masa depan anak lebih bahagia dan percaya diri. Beberapa perilaku yang menunjukkan kesehatan moral adalah berani, semangat, disiplin dan bahagia.

Keberanian anak menjadi modal yang penting dalam memaksimalkan potensi dalam mengambangkan kemampuan anak. Anak dalam pola asuh orangtua yang demokratis, anak termasuk anak yang berani, seperti misalnya ketika diminta maju ke depan kelas dan mempraktikan percobaan balon dan api dan mau mencoba. Anak dalam pola asuh orangtua yang otoriter, dalam kegiatan akademik seperti tanya jawab, berargumen bercerita anak sudah berani tetapi ketika diminta maju ke depan kelas/melakukan percobaan/kegiatan sendiri anak masih sering ragu. Anak dalam pola asuh orangtua yang permisif, keberaniaannya muncul dalam hal akademik, namun dalam hal sosial ketika bemain denan temannya dan berbuat kesalahan, anak seringkali menyalahkan temannya untuk mencari perlindungan.

Bentuk perilaku hidup sehat mental yang tak kalah penting adalah semangat. Anak dengan pola asuh demokratis, sangat antusias dalam mengikuti berbagai hal di sekolah. Anak dengan pola asuh otoriter, semangatnya muncul di awal saja, selebihnya tergantung mood. Anak dengan pola asuh permisif, anak masih belum stabil moodnya karena kadangkala semangat ke sekolah, namun tak jarang murung di sekolah dan emangatnya bisa muncul lagi kalau ananda di berikan reward.

Disiplin merupakan salah satu perilaku yang harus dimiliki dan dibiasakan dari dini. Anak dengan pola asuh demokratis, anak yang disiplin patuh dan taat kepada aturan di sekolah dan dirumah bahkan aturan yang ada dirumah terkadang diterapan. Anak dengan pola asuh otoriter, anak yang disiplin, datang ke sekolah tepat waktu juga taat dan patuh pada aturan di sekolah. Anak dengan pola asuh permisif, anak seringkali melanggar aturan di kelas seperti ketika 
diingatkan selalu mengalihkan pembicaraan dan ketika mendapatkan konsekuensi ananda selalu mencari kesalahan temannya yang lain.

Bahagia adalah kunci kehidupan. Orang yang selalu bahagia akan mudah mendapatkan banyak orang yang mencintainya. Anak dengan pola asuh demokratis, Anak bisa mengatur perasaan dengan baik. Anak seringkali terlihat gembira dan ceria ketika masuk ke sekolah dan mengikuti semua kegiatan dengan antusias. Anak dengan pola asuh otoriter, Anak masih belum bisa mengatur perasaanya dengan baik, seperti ketika belum dijemput, anak langsung menangis tanpa mau mendengaran penjelasan terlebih dahulu atau ketika ananda terlambat menyelesaikan tugas, ketika diingatkan ananda justru menangis juga. Anak dengan pola asuh permisif, moodnya masih belum stabil sepeti bisa saja pagi sedih dan meangis, tapi agak siang sudah ceria lagi.

Perilaku hidup sehat mental anak, setiap orangtua berkewajiban untuk itu. Kesadaran orangtua juga dapat dilihat dari jawaban atau tanggapan orangtua atas laporan di combook yang ditulis oleh guru. Pernyataan atau laporan guru tentang kedisiplinan anak di sekolah dan jawaban ketiga orangtua dalam buku penghubung tersebut sama yaitu orangtua anak telah mencoba mengajarkan dan membiasakan anak untuk besikap disiplin, misalnya dalam menetapkan waktu belajar kepada anak dan peraturan lainnya yang telah diberikan orangtua di rumah. Hal tersebut sedikit berbeda dengan pernyataan guru yang mengajar di kelas, yaitu: "Ya, namanya anak, kadang pengen seenaknya sendiri tetapi juga kalau dibimbing dan dibiasakan untuk mengikuti aturan, insyallah bisa walau masih beberapa murid selalu harus diawasi dan dibisakan dan beberapa sudah sadar atas bagaimana berperilaku baik."

\section{Pembahasan}

Keluarga merupakan wadah pertama dalam proses pendidikan yang menanamkan nilai-nilai luhur yang dimiliki bangsa kepada anak. Hal tersebut sejalan dengan pendapat Karimah, Nurwati, \& Basar (2014) yang menyatakan bahwa keluarga memiliki delapan fungsi penting, yaitu fungsi agama, reproduksi, kasih sayang, perlindungan, ekonomi, sosialisasi dan pendidikan, pelestarian lingkungan, dan sosial budaya sehingga mampu membentuk keluarga yang memiliki ketahanan hingga terbentuknya ketahanan nasional. Beberapa fungsi orangtua tersebut menjadikan kewajiban orangtua untuk mendidik, menjaga, dan melindungi harus dilakukan dengan baik, salah satunya adalah menjaga kesehatan anak atau untuk membentuk perilaku hidup sehat anak. Hal tersebut sejalan dengan pendapat Ayun (2016) yang menyatakan bahwa pendidikan merupakan salah satu faktor penting yang harus diberikan kepada anak dalam perspektif islam yaitu pendidikan spiritual (keimanan), moral (akhlak), fisik, akal, psikis, seksual, dan sosial yang dapat dilihat dari perilaku hidup sehat anak terutama pada spiritual, moral, dan fisik anak.

Perilaku hidup sehat anak dapat dilihat dari tiga bagian yaitu perilaku hidup sehat spiritual (menjaga kebersihan diri dan lingkungannya, ibadah, akhlak, dan budi pekerti anak atau hubungan dengan orang lain), fisik (menjaga kesehatan, kerapian dan toilet training), dan moral (berani, semangat, disiplin dan bahagia). Bentuk perilaku hidup sehat sangat bergantung kepada pola asuh yang dilakukan oleh orangtua, apalagi orangtua yang bekerja karena waktu bersama anak yang terbatas. 
Bentuk perilaku hidup sehat spiritual dari anak yang kedua orangtuanya bekerja dapat dilihat dari anak mampu dan mau untuk menjaga kebersihan diri dan lingkungannya, ibadah, akhlak, dan budi pekerti anak atau hubungan dengan orang lain. Dari hasil penelitian maka perilaku sehat spiritual yang terlihat di sekolah menunjukkan bahwa anak yang diasuh dari pola asuh yang demokatis, mampu berperilaku baik dalam menjaga kebersihan, kegiatan ibadah, akhlak yang baik, dan budi pekerti (sopan dan santun). Anak yang diasuh dari pola asuh yang otoriter, mampu berperilaku baik dalam menjaga kebersihan, kegiatan ibadah, dan akhlak yang baik tetapi masih harus sering diingatkan dalam berperilaku sopan dan santun kepada orang lain/orang yang lebih tua (guru). Anak yang diasuh dari pola asuh yang permisif, masih harus selalu diingatkan dalam menjaga kebersihan, kegiatan ibadah, akhlak yang baik, dan budi pekerti (sopan dan santun).

Perbedaan perilaku hidup sehat spiritual tersebut sangat berhubungan dengan kedekatan antar keluarga terutama antara anak dan orangtua. Hal tersebut diperkuat dengan teori yang dikemukakan oleh Sujana, Fatimah, \& Hidayati (2017) yang menyatakan bahwa ikatan keluarga yang sangat erat inilah kebutuhan keluarga terhadap hubungan (relationship) bukan menjadi kebutuhan yang dirasa sangat penting karena keluarga sudah mendapat dukungan dari anggota keluarganya sendiri, sehingga setiap terjadi krisis atau penyakit keluarga lebih membutuhkan keyakinan kepada Tuhan yang menjadi sumber kekuatan baginya. Perilaku hidup sehat spiritual atau pendidikan agama dalam keluarga yang baik juga menjadi kunci hubungan yang harmonis antar keluarga. Hal tersebut sejalan dengan pendapat Sukaimi (2013) yang menyatakan bahwa keluarga merupakan pusat dalam proses pendidikan, agama, serta latihan dan pusat kebudayaan sehingga hubungan antar anggota keluarga sebaiknya harus selalu terpadu dan harmonis, bergotong-royongan, kasih sayang, dan kerjasama yang baik.

Perilaku hidup sehat spiritual juga harus didukung oleh perilaku hidup sehat lainya termasuk perilaku hidup sehat fisik. Perilaku hidup sehat fisik menjadi hal penting karena sangat berhubungan dengan kesehatan yang harus diperhatikan oleh orangtua apalagi yang memiliki waktu terbatas dengan anak karena bekerja. Sehat secara fisik akan selalu menunjukan kesehatan yang tampak secara fisik sebagai faktor utama dalam penentuannya. Beberapa perilaku yang menunjukkan kesehatan fisik adalah kegiatan untuk menjaga kesehatan, kerapian dan toilet training. Hasil penelitian ini menunjukkan bahwa anak yang diasuh dari pola asuh yang demokatis, kerapian dan melakukan toilet training, anak melakukannya dengan sangat baik tetapi beberapa kali izin karena sakit. Anak yang diasuh dari pola asuh yang otoriter, kerapian anak dijaga dengan baik tetapi dalam hal kegiatan motorik dan toilet training, anak belum menguasainya. Anak yang diasuh dari pola asuh yang permisif, mampu melakukan kegiatan motorik, selalu rapi dan menarik, juga toilet training dengan baik.

Perbedaan perilaku hidup sehat fisik sepenuhnya bergantung pada bagaimana orangtua bertanggung jawab dalam pemenuhan hak-hak dalam segi pertumbuhan dan kesehatan fisik. Hal tersebut diperkuat oleh pendapat (Strohschein \& Gauthier, 2018) yang menyatakan bahwa perilaku hidup sehat yang mengarah kepada kesehatan fisik anak yang buruk akan menjadi penghambat dalam mencapai pendidikan dan pendapatan yang rendah di masa 
depan atau ketika dewasa. Hal tersebut juga sejalan dengan pendapat Indriati, Suyadi, Wahyoeningsih, \& Sanyoto (2017) yang menyatakan bahwa pemenuhan dan perlindungan hak anak menjadi tanggung jawab orangtua, tetapi dalam kenyataannya anak berada pada perlindungan oranglain serta pemenuhan hakhak anak dari segi pertumbuhan fisik, kesehatan, keadaan bahaya, dan pendidikan tidak terpenuhi atau terabaikan. Pemenuhan hak-hak anak termasuk hak untuk hidup sehat secara fisik dari pemenuhan gizi dan lain-lain sangatlah bergantung kepada orangtua. Pemenuhan hak-hak anak dalam pembentukan perilaku hidup sehat secara fisik juga sejalan dengan pendapat Siregar (2018) yang menyatakan bahwa anak tidak dapat melindungi diri sendiri dalam penghidupan dan kehidupan dari berbagai ancaman baik mental, sosial, dan fisik karena itu anak seharusnya mendapatkan bantuan dari orang lain dalam upaya melindungi dirinya dari berbagai kondisi dan situasi.

Perilaku hidup sehat spiritual dan fisik yang berbeda pada setiap pola asuh yang dilakukan oleh orangtua yang bekerja ternyata juga berbeda pada perilaku hidup sehat moral. Perilaku hidup sehat moral menjadi hal yang tak kalah pentingnya menyangkut perilaku hidup sehat. Beberapa perilaku yang menunjukkan kesehatan moral adalah berani, semangat, disiplin dan bahagia. Hasil penelitian menunjukkan bahwa anak yang diasuh dari pola asuh yang demokatis, menunjukan semua aspek baik keberanian, semangat, disiplin dan bahagia, ditunjukkan anak dengan baik. Anak yang diasuh dari pola asuh yang otoriter, menunjukan semua aspek baik keberanian, disiplin dan bahagia, ditunjukkan anak dengan baik tetapi moodnya masih belum stabil. Anak yang diasuh dari pola asuh yang permisif, keberaniannya baik tetapi masih harus dibimbing dalam aspek lainya baik semangat, disiplin dan bahagia.

Perbedaan perilaku hidup sehat moral ternyata tidak bisa dipisahkan dengan pola asuh orangtua yang telah dilakukan dan tidak terlepas dari perilaku spiritual dan fisik yang dimiliki anak. Hal tersebut sejalan dengan pendapat Laa (2018) yang menyatakan bahwa pola asuh yang diberikan oleh orangtua sangat mempengaruhi perkembangan moral anak dalam berperilaku terutama dalam perilaku hidup sehat anak di dalam kehipudannya. Hak anak tentang hidup bermasyarakat karean moral menjadi hal terpenting dalam kehidupan bermasyarakat hingga penanaman nilai moral harus menjadi perhatian khusus oleh orangtua. Penanaman moral yang baik juga akan menjadi upaya perlingungan yang tepat untuk anak dalam menjalani kehidupan selanjutnya dengan baik.

Hubungan ketiga perilaku tersebut saling berhubungan dan tidak dapat terpisahkan dalam perilaku hidup sehat anak dan sangat bergantung kepada pola asuh yang dilakukan orangtua, apalagi orangtua yang bekerja. Hal tersebut sejalan dengan pendapat Rakhmawati (2015) yang menyatakan bahwa hubungan perilaku hidup sehat spiritual, fisik, dan moral tidak bisa dipisahkan yang menyatakan bahwa orangtua harus memantapkan diri dalam hal agama dan menanamkan nilai-nilai agama yang suci dan luhur kepada anak-anaknya karena dari cahaya keimanan dan ketakwaan yang suci inilah keagungan moral dan ketinggian budi akan menyinari perilaku dan kesehatan fisik seseorang dalam kehidupan sehari-hari.

Agama atau spiritual akan membawa perilaku moral yang baik dan kesehatan fisik dari bentuk menjalani kehidupan sehari-hari dengan baik juga 
menjadi jalan dalam hidup sehat. Orangtua menjadi kunci dalam menjalani hidup sehat baik secara spiritual, fisik dan mental anak sehingga waktu dan interaksi orangtua dan anak sangat penting walaupun orangtua harus bekerja karena sudah merupakan tanggung jawab sebagai orangtua dalam memenuhi hak anak. Hal tersebut sejalan dengan pendapat Novrinda, Kurniah, \& Yulidesni (2017) yang menyatakan bahwa tanggung jawab dan upaya terhadap pemenuhan hak dan kebutuhan anak menjadi tugas utama orangtua. Keluarga atau orang tua atau wali merupakan pihak utama yang memiliki kewajiban untuk memberikan pemeliharaan, pemenuhan kesejahteraan sosial, dan perlindungan kepada anak. Perlindungan kepada anak bukan hanya untuk anak yang memiliki keluarga tetapi juga yang tidak memiliki keluarga. Negara akan menunjukkan tanggung jawabnya jika memang seorang anak tidak memiliki keluarga. Hal tersebut dipaparkan oleh Sandi (2016) yang menyatakan bahwa Negara berkewajiban memberikan perlindungan, kesejahteraan, dan pemeliharaan apabila orangtua atau keluarga tidak memiliki kemampuan untuk memenuhi tanggung jawabnya.

\section{SIMPULAN}

Orangtua memiliki kewajiban dalam hal mengasuh dan melindungi anak walaupun bekerja. Tidak ada alasan apapun untuk menelantarkan anak dan mengabaikan anak. Memilih pola asuh yang tepat kepada anak menjadi faktor yang sangat penting. Perilaku hidup sehat menjadi kunci hidup dengan baik dan bahagia. Anak dalam pola asuh demokratis dari orangtua yang bekerja, memiliki perilaku hidup sehat yang baik. Seluruh bagian dalam hidup sehat baik secara spiritual, fisik, dan moral ditunjukkan dengan baik. Anak dalam pola asuh otoriter dari orangtua yang bekerja, masih harus diingatkan dan dibimbing dalam hal sopan santun, diberi semangat dalam kegiatan motorik/fisik, juga dilatih toilet training sedangkan anak dalam pola asuh permisif dari orangtua yang bekerja, masih harus dibimbing dalam segala aspek, baik spiritual, fisik, maupun moral. Anak tumbuh dan berkembang sesuai apa yang diajarkan, dibiasakan, dan dirasakan. Pola asuh bukan tentang benar atau yang salah, hanya saja orangtua harus mampu memilih pola asuh yang tepat dan mengorbankan waktu lebih lama dengan anak. Kasih sayang bukan hanya terbentuk dari kecukupan materi tetapi juga waktu bersama keluarga karena waktu tak akan terulang.

\section{UCAPAN TERIMA KASIH}

Lembaga Pengelola Dana Pendidikan (LPDP) Indonesia telah memberikan dukungan berupa dana penelitian atau penyandang dana atau sponsor sehingga dapat menyelesaikan penelitian ini dengan baik.

\section{DAFTAR PUSTAKA}

Astuti, A. K. (2016). Pelaksanaan Perilaku Sehat Pada Anak Usia Dini Di PAUD Purwomukti Desa Batur Kecamatan Getasan. Jurnal Scholaria, 6(3).

Ayun, Q. (2016). Pendidikan Dan Pengasuhan Keluarga Dalam Membentuk Perkembangan Kepribadian Anak: Perspektif Psikologi Perkembangan Islam. ATTARBIYAH, 26, 91-118. https://doi.org/doi: 10.18326/attarbiyah.v26.91-118

Berangka, D. (2018). Pengaruh Pola Asuh Orang Tua, Budaya Sekolah Dan Motivasi Belajar Terhadap Disiplin Belajar Siswa SMP Di Lingkungan YPPK 
Distrik Merauke. Jurnal Jumpa, 6(1).

Cabrera, N. J., Volling, B. L., \& Barr, R. (2018). Fathers Are Parents, Too! Widening the Lens on Parenting for Children's Development. Child Development Perspectives, 12(3), 152-157. https://doi.org/10.1111/cdep.12275

Farzana Bibi, F. B. (2013). Contribution of Parenting Style in life domain of Children. IOSR Journal of Humanities and Social Science, 12(2), 91-95. https://doi.org/10.9790/0837-1229195

Garcia, O. F., \& Serra, E. (2019). Raising children with poor school performance: parenting styles and short-and long-term consequences for adolescent and adult development. International Journal of Environmental Research and Public Health, 16(7), 14-17. https://doi.org/10.3390/ijerph16071089

Gibbs, B. G., Forste, R., \& Lybbert, E. (2018). Breastfeeding, Parenting, and Infant Attachment Behaviors. Maternal and Child Health Journal, 22(4), 579-588. https://doi.org/10.1007/s10995-018-2427-z

Haeriah, B. (2018). Pengaruh Pola Asuh Orang Tua Terhadap Kemandirian Anak Kelompok B Taman Kanak-Kanak PGRI Gerunung Tahun Pelajaran 2017/2018. JIME, 4(1).

Harmaini. (2013). Keberadaan Orang Tua Bersama Anak. Jurnal Psikologi, 9(2).

Hutchens, A., \& Lee, R. E. (2018). Parenting Practices and Children's Physical Activity: An Integrative Review. Journal of School Nursing, 34(1), 68-85. https://doi.org/10.1177/1059840517714852

Indonesia, P. (2009). Undang-Undang Kesehatan Republik Indonesia No.36 Tahun 2009. Jakarta: Sekertariat Negara.

Indriati, N., Suyadi, Wahyoeningsih, K. K., \& Sanyoto. (2017). Perlindungan Dan Pemenuhan Hak Anak (Studi Tentang Orang Tua Sebagai Buruh Migran Di Kabupaten Banyumas). Mimbar Hukum, 29(3).

Juliani, R. (2018). Pelaksanaan Perilaku Hidup Bersih Dan Sehat (PHBS) Di Lingkungan Sekolah. Jurnal Ilmiah Potensia, 3(1).

Karimah, D., Nurwati, N., \& Basar, G. G. K. (2014). Pengaruh Pemenuhan Kesehatan Anak Terhadap Perkembangan Anak. Prosiding KS: Riset \& PKM, 2(1).

Laa, R. (2018). Pola Asuh Anak Dalam Keluarga Petani Di Domloli Kabupaten Alor. AL-ASASIYYA: Journal Basic Of Education, 3(1).

Marzuki, M. B., \& Mahiruni, S. K. (2020). Stunting di Jatim Tinggi, Gubernur Khofifah Dorong Pola Hidup Bersih dan Sehat. Jatimtimes.Com. Retrieved from https://jatimtimes.com/baca/207549/20200111/172800/stunting-dijatim-tinggi-gubernur-khofifah-dorong-pola-hidup-bersih-dan-sehat

Muhadi, A. I. (2015). Hubungan Pola Asuh Demokratis Terhadap Kemandirian Anak Di Taman Kanak-Kanak El Hijaa Tambak Sari Surabaya. Tadarus: Jurnal Pendidikan Islam, 4(1).

Novrinda, Kurniah, N., \& Yulidesni. (2017). Peran Orangtua Dalam Pendidikan Anak Usia Dini Ditinjau Dari Latar Belakang Pendidikan. Potensia, 2(1).

Nugroho, A. (2019). radar kediri. Radar Kediri Jawa Pos. Retrieved from https://radarkediri.jawapos.com/read/2019/10/01/158585/penelantarananak-dan-lansia-di-kediri-sepuluh-kasus-dalam-9-bulan

Padjrin. (2016). Pola Asuh Anak dalam Perspektif Pendidikan Islam. Intelektualita, 5(1). Retrieved from http://jurnal.radenfatah.ac.id/index.php/intelektualita 
Rakhmawati, I. (2015). Peran Keluarga Dalam Pengasuhan Anak. Konseling Religi: Jurnal Bimbingan Konseling Islam, 6(1).

Rhamadani Santoso, V., Nasution, Z., \& Sri Redjeki, E. (2016). Pola Pengasuhan Ibu Bekerja Dalam Menstimulasi Perkembangan Anak Usia Dini. Jurnal Pendidikan Nonformal, 12(2), 77-91.

Sandi, I. (2016). Implementasi Kebijakan Perlindungan Anak Terlantar Pada Dinas Sosial Provinsi Sulawesi Tengah. E Jurnal Katalogis, 4(1).

Shabarina, A., Mediani, H. S., \& Mardiah, W. (2018). Pola Asuh Orang Tua yang Menitipkan Anak Prasekolah di Daycare Kota Bandung. Jurnal Pendidikan Keperawatan Indonesia, 4(1), 68. https://doi.org/10.17509/jpki.v4i1.12344

Siregar, H. (2018). Peranan Pusat Kajian Perlindungan Anak Dalam Menjalankan Hak Asasi Anak Jalanan Ditinjau Dari Pasal 11 Undang-Undang Nomor 23 Tahun 2002 Tentang Perlindungan Anak. Jurnal Civics: Media Kajian Kewarganegaraan, 15(1).

Siti Juwariah, K. (2019). Analysis of Parenting and Involvement of Parents in Early Childhood. Journal of Primary Education, 8(3), 364-370.

Strohschein, L., \& Gauthier, A. H. (2018). Poverty Dynamics, Parenting, and Child Mental Health in Canada. Society and Mental Health, 8(3), 231-247. https://doi.org/10.1177/2156869317731603

Sujana, S., Fatimah, S., \& Hidayati, N. O. (2017). Kebutuhan Spiritual Keluarga Dengan Anak Penderita Penyakit Kronis. Jurnal Pendidikan Keperawatan Indonesia, 3(1).

Sukaimi, S. (2013). Peran Orang Tua Dalam Pembentukan Kepribadian Anak: Tinjauan Psikologi Perkembangan Islam. Marwah, 12(1).

Susanti, E., \& Kholisoh, N. (2018). Konstruksi Makna Kualitas Hidup Sehat (Studi Fenomenologi pada Anggota Komunitas Herbalife Klub Sehat Ersanddi Jakarta). Jurnal Lugas, 2(1).

Wang, Y., Huang, Z., \& Kong, F. (2020). Parenting stress and life satisfaction in mothers of children with cerebral palsy: The mediating effect of social support. Journal of Health Psychology, 25(3), 416-425. https://doi.org/10.1177/1359105317739100

Widiasari, Y., \& Pujiati, D. (2017). Pengasuhan Anak Usia Dini Bagi Orang Tua Pekerja. JURNAL INDRIA (Jurnal Ilmiah Pendidikan Prasekolah Dan Sekolah Awal), 2(2), 68-77. https://doi.org/10.24269/jin.v2n2.2017.pp68-77 